\title{
Casein kinase G may be the target of spermine during progesterone-induced oocyte maturation
}

\author{
LI RUNSHeng AND JIAKE TSO ${ }^{1}$ \\ Shanghai Institute of Cell Biology, Academia Sinica
}

\section{ABSTRACT}

Casein kinase G (CKG) with more than 2500 -fold enrichment was purified from Bufo bufo gargarizans ovaries. The catalytic activity of the enzyme was found to be associated with its $42 \mathrm{kD}$ subunit, and its $26 \mathrm{kD}$ subunit was found to be the major target for the enzyme autophosphorylation. Each full-grown oocyte contained 1.9 units of CKG corresponding to an intracellular concentration of $93 \mathrm{n} M$. After injecting an amount of 0.38 units of the enzyme into the oocyte, approximately $50 \%$ of the progesterone-induced maturation was inhibited. The inhibitory effect was enhanced in oocytes pretreated with spermine, which was consistent with the results that the enzyme was activated in vitro in the presence of spermine. The MPF-induced oocyte maturation was delayed and even prohibited in the kinase-microinjected oocytes. A $55 \mathrm{kD}$ oocyte protein was identified as an substrate of CKG both in vivo and in vitro, and the enhancement of the $55 \mathrm{kD}$ protein phosphorylation was associated with kinase inhibition on maturation and on protein synthesis in kinase-microinjected oocytes. As the endogenous spermine level decreased in the course of progesteroneinduced oocyte maturation, $55 \mathrm{kD}$ protein was dephosphorylated. Heparin, a specific inhibitor of CKG, potentiated the progesterone-induced oocyte maturation. Altogether the experimental results indicated strongly that CKG may be the physiological target of spermine.

Key words: casein kinase $G$, spermine, toad oocyte, progesterone induced maturation.

\section{INTRODUCTION}

Reversible protein phosphorylation has emerged as one of the major mechanisms

1. Corresponding author 
Casein kinase $\mathrm{G}$ involves in oocyte maturation.

by which a living cell may regulate a lot of its metabolic state, especially in response to a number of hormonal or neural effectors[1]. The process of oocyte maturation is of great interest to be used as a model for studying cell cycle regulated by protein phosphorylation-dephosphorylation. It has been well known that cAMP-dependent protein kinase[2], protein kinase C[3], ribosomal S6 protein kinase[4], the protein kinase of MPF[5] and other unidentified protein kinases[6,7] were all implicated in the process of progesterone-induced amphibian oocyte maturation. In addition, we have indicated that a $55 \mathrm{kD}$ protein was dephosphorylated during the progesteroneinduced oocyte maturation[8]. The triggering of $55 \mathrm{kD}$ protein phosphorylation may be resulted from the progesterone-stimulated reduction of endogenous level of spermine, so it is worthy to elucidate the mechanism of $55 \mathrm{kD}$ protein phosphorylation promoted by spermine.

Phosphatase activity was decreased while protein kinase activity was increased in the cellular extract of mammalian tissues in the presence of spermine. A kind of protein kinase may be the target of spermine in oocytes, owing to the fact that phosphatase inhibitors delayed but did not inhibit oocyte maturation, while spermine could inhibit oocyte maturation[8]. Among all protein kinases in oocyte that have been investigated, only casein kinase $\mathrm{G}$ and some tyrosine kinase activities were found to be increased in the presence of polyamines. It seemed that CKG was the most interesting one since polyamines exerted their effect on its activity at a physiological concentration range[9]. Furthermore, CKG is a kind of kinase existing both in the nucleus and cytoplasm of a wide variety of eukaryocytes, and is able to utilize both ATP and GTP as phosphoryl donor in the phosphotransferase reaction. The enzyme consists of $\alpha$ and $\beta$ subunits with a molecular weight of $38-44 \mathrm{kD}$ and $24-28 \mathrm{kD}$ respectively. The $\alpha$ subunit contains ATP binding site and is a catalytic subunit. The $\beta$ subunit contains an acceptor site for autophosphorylation and is a regulatory subunit. CKG is also characterized by its remarkable heparin sensitivity and is able to be activated by its phosphorylation[9, 10$]$.

Regulation of CKG activity in vitro is quite an attractive subject, since the change of its activity is associated with cell differentiation[10], embryonic development and tumour cell proliferation[11]. Therefore, we decided to investigate the effect of CKG on progesterone induced oocyte maturation, and explore its possible mechanism.

\title{
MATERIALS AND METHODS
}

\author{
Materials \\ Bufo bufo garagarizans were obtained from Jiangsu Province in December, and then kept in a \\ cold room $\left(4{ }^{\circ} \mathrm{C}\right)$ to maintain the full-grown oocytes sensitive to the stimulation by progesterone. \\ Phosvitin, casein, protamine, histone (Type II-AS), calmodulin, protein kinase inhibitor, polyamines \\ cAMP, unlabelled nucleotides, heparin and heparin-agarose were all obtained from Sigma. DEAE- \\ cellulose (DE52) and phosphocellulose (P11) were purchased from Pharmacia Fine Chemicals. $\gamma$ - \\ ${ }^{32} \mathrm{P}$-ATP and ${ }^{32} \mathrm{P}$-GTP $(10 \mathrm{Ci} / \mathrm{mmol}$ ) were obtained from Amersham. \\ Extraction and purification of protein kinase $G$ from toad Ovaries
}


$74 \mathrm{~g}$ of fresh ovarian tissue obtained from female toads were washed with 10 volumes of ice-cold homogenization buffer (200 $\mathrm{m} M$ sucrose, $2 \mathrm{~m} M$ DL-dithiothreitol, $1.0 \mathrm{mM}$ L-1-tosyl-phenylanylchloromethane, $1.0 \mathrm{~m} M$ phenylmethane sulfonly fluoride, $5 \mathrm{~m} M$ EDTA and $5 \mathrm{~m} M$ EGTA in 50 $\mathrm{m} M$ Tris/ $\mathrm{HCl} \mathrm{pH} \mathrm{7.1)} \mathrm{and} \mathrm{then} \mathrm{were} \mathrm{homogenized} \mathrm{thoroughly} \mathrm{in} \mathrm{fresh} \mathrm{cold} \mathrm{homogenization} \mathrm{buffer}$ ( $80 \mathrm{ml}$ ). Unbroken cells were discarded by $10 \mathrm{~min}$ centrifugation at $1000 \times \mathrm{g}$, followed by $30 \mathrm{~min}$ centrifugation at $2000 \times$ g. The supernatant, i.e. the crude cytosolic extract, was either assayed directly for protein kinase activity, or after centrifugation at $100,000 \times \mathrm{g}$ for $1 \mathrm{~h}$ at at $2^{\circ} \mathrm{C}$ to remove lysosomes and other membrane vesicles, except ribosomes. For further purification, the 100,000 $\times$ g supernatant was successively submitted to DEAE-cellulose chromatography, phosphocellulose chromatography and heparin-agarose chromatography.

DEAE-cellulose (DE 52) chromatography- $68 \mathrm{ml}$ of DEAE- cellulose previously equilibrated with $500 \mathrm{ml}$ of buffer A ( $1 \mathrm{~m} M$ DL-dithiothreitol and $1 \mathrm{~m} M$ EDTA in $10 \mathrm{~m} M$ Tris/ HCl pH 7.1) were stirred gently overnight at $4^{\circ} \mathrm{C}$, then transferred into a column $(2.0 \mathrm{~cm}$ in diameter $)$ and washed with $400 \mathrm{ml}$ of buffer A. After pipetting the $100,000 \times \mathrm{g}$ supernatant onto the cellulose column surface, the column was eluted with $400 \mathrm{ml}$ of linear gradient of $\mathrm{NaC} 1$ (ranging from 0 to $0.5 \mathrm{M}$ ) in buffer A at a flow rate of $30 \mathrm{ml} / \mathrm{h}$ and $10 \mathrm{ml}$ fractions were collected. Aliquots of $10 \mu \mathrm{l}$ from each fraction were submitted to the protein kinase assay. Fractions containing the kinase activity were pooled together.

Phosphocellulose chromatography-Solid ammonium sulfate was added to pool from DE-52 column to $80 \%$ saturation. The precipitate was collected after $10 \mathrm{~h}$ of gentle stirring at $4{ }^{\circ} \mathrm{C}$, and then dissolved in a minimal volume of buffer B (10 m $M$ mercaptoethanol, $1 \mathrm{~m} M$ EDTA, $200 \mathrm{~m} M \mathrm{NaCl}$

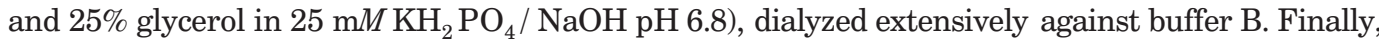
the sample was pumped onto a $8 \mathrm{ml}$ column $(1.0 \times 11 \mathrm{~cm})$ of phosphocellulose equilibrated with buffer $\mathrm{B}$, and was eluted with 7 bed volume of gradient ranging from $0.2 M$ to $1.5 \mathrm{M}$ of $\mathrm{NaCl}$ in buffer B. Fractions of $1.0 \mathrm{ml}$ were collected at the flow rate of $15 \mathrm{ml} / \mathrm{h}$. Aliquots for protein kinase activity assay were diluted with 20 volumes of buffer A.

Heparin-agarose chromatography-Fractions containing the protein kinase activity obtained from the phosphocellulose chromatography were pooled together and dialyzed extensively against buffer A. Then it was disposed onto a column of heparin-agarose $(2 \times 3 \mathrm{~cm})$ previously equilibrated with buffer A, and was eluted with $30 \mathrm{ml}$ of gradient eluant ranging from 0 to $2.0 \mathrm{M}$ of NaCl in buffer A. the flow rate was $7.8 \mathrm{ml} / \mathrm{h}$ and fractions of $1.0 \mathrm{ml}$ were collected. Aliquots obtained from each fraction were diluted with 4 volumes of buffer A for the protein kinase activity assay, since the dilution was necessary for reducing the effect of sodium in fractions on the protein kinase activity.

\section{Protein kinase assay}

Protein kinase assay were performed by incubating the enzyme or enzyme source (10 $\mu \mathrm{l})$ in a reaction mixture (final volume $100 \mu \mathrm{l}$ ) containing $120 \mathrm{~m} M \mathrm{KCl}, 10 \mathrm{~m} M \mathrm{MgCl}_{2}$ and $12 \mu M_{\gamma}{ }^{32} \mathrm{P}$-ATP or $\gamma-{ }^{32} \mathrm{P}-\mathrm{GTP}$ in $25 \mathrm{mM}$ Tris/HCl pH 7.1, and $200 \mu$ g casein which had been dephosphorylated as described by Hathaway et al[12]. The reaction was started with the addition of nucleotide. After 15 min of incubation at $33^{\circ} \mathrm{C}$, all the samples were pipetted from each tube, spotted on a $1.5 \times 1.5 \mathrm{~cm}$ square Whatman No.3 filter-paper and rapidly immersed in $10 \%$ trichloroacetic acid to terminate the reaction. The filters were then processed for washing as already described by Boyer et al[13]. Parallel experiments were performed in the absence of the enzyme. The radioactivity was measured by a liquid scintillation counter Beckman L9800. One enzyme unit (U) was defined as the amount of enzyme which catalyzed the incorporation of $1 \mathrm{pmol}^{32} \mathrm{P}$ per minute under standard conditions. In other cases, reactions were quenched by the addition of electrophoresis buffer which stopped the activity immediately.

\section{Casein kinase $G$ microinjection}

Fractions containing protein kinase activity from heparin-agarose chromatography were pooled 
Casein kinase $\mathrm{G}$ involves in oocyte maturation.

together and dialyzed against $140 \mathrm{ml}$ of kinase buffer $(200 \mathrm{~m} M \mathrm{NaCl}, 1 \mathrm{~m} M$ DTT and $1 \mathrm{~m} M$ EDTA in $20 \mathrm{~m} M$ Tris/HCl pH 7.4) containing saturated ammonium sulfate for $10 \mathrm{~h}$. Then it was submitted to centrifugation for $30 \mathrm{~min}$ at $12,000 \times \mathrm{g}$. The precipitate was collected and dissolved in a minimal volume of the kinase buffer containing $1 \mathrm{mg} / \mathrm{ml}$ bovine serum albumin(BSA). The concentrated enzyme preparation was dialyzed further against $100 \mathrm{ml}$ of the kinase buffer overnight, and centrifugated for $40 \mathrm{~min} 12,000 \times \mathrm{g}$. The supernatant was used as CKG for microinjection. The final preparation was diluted with the kinase buffer containing BSA according to needs. Although $\mathrm{Mg}^{2+}$ was necessary for the kinase assay in vitro (see results), it should be excluded from kinase buffer, since $\mathrm{Mg}^{2+}$ alone can enhance progesterone stimulation[14]. The kinase injection was performed as described elsewhere[8], and cold light source was used for the illumination of microinjection.

\section{Other methods}

Proteins labeled with ${ }^{32} \mathrm{P}$ in vitro and in vivo were separated by SDS polyacrylamide gel (7.515\% gradient ) electrophoresis (PAGE) according to Laemmli[15] and Li et al[8]. The gels were dried and exposed to Kodak X-Omat film at $-20{ }^{\circ} \mathrm{C}$ for autoradiogrphy.

Measurement of protein kinase activity after SDS-PAGE was performed with a method similar to that described by Cochet et al[9] with some modifications. The slices obtained from the gel were homogenized in $80 \mu \mathrm{l}$ of the kinase buffer containing $1 \mathrm{mg} / \mathrm{ml}$ BSA. Each slice homogenate was incubated for $2 \mathrm{~h}$ at $33^{\circ} \mathrm{C}$ with $20 \mu$ l kinase buffer containing 5-10 $\mu M \gamma^{32}{ }^{32} \mathrm{P}$-ATP, $50 \mathrm{~m} M$ $\mathrm{MgCl}_{2}$ and $6 \mathrm{mg} / \mathrm{ml}$ casein: The protein substrate was omitted when autophosphorylation of the kinase was studied. The suspension was then submitted to centrifugation and the gel pellet was washed twice with $0.5 \mathrm{ml}$ of boiling trichloroacetic acid (10\%), neutailized by $50 \mu \mathrm{l}$ of $0.5 \mathrm{~N} \mathrm{HCl}$, and counted for ${ }^{32} \mathrm{P}$ incorporation.

Protein estimation was carried out according to the procedures of Bradford[16] with BSA as the standard, $\mathrm{pH}$ was measured at $4{ }^{\circ} \mathrm{C}$. Oocyte preparation was carried out as described previously[8].

\section{RESULTS}

\section{Identification of casein kinase $G$ in the enzyme preparations}

CKG with more than 2500 fold enrichment was purified from Bufo bufo gargarizans ovaries (Tab 1). All experiments concerning the characterization of CKG were performed with materials derived from heparin-agarose active fractions.

Tab 1. Summary of purification of Casein kinase G from ovaries.*

\begin{tabular}{|c|c|c|c|c|c|}
\hline $\begin{array}{l}\text { Purification } \\
\text { steps }\end{array}$ & $\begin{array}{l}\text { Total protein } \\
(\mathrm{mg})\end{array}$ & $\begin{array}{l}\text { Enzyme activty } \\
\text { (umt /mg) }\end{array}$ & $\begin{array}{c}\text { Total activity } \\
\text { (unit) }\end{array}$ & $\begin{array}{l}\text { Purification } \\
\text { (fold) }\end{array}$ & $\begin{array}{r}\text { Yield } \\
(\%)\end{array}$ \\
\hline $2,000 \times$ g supernatant & 2,240 & 41 & 92,000 & 1 & 100 \\
\hline $100,000 \times \mathrm{g}$ supernatant & 1,085 & 81 & 88,400 & 2 & 96 \\
\hline DEAE-Cellulose & 60.0 & 1,335 & 79,000 & 33 & 83 \\
\hline Phosphocellulose & 4.1 & 12,307 & 50,500 & 300 & 55 \\
\hline Heparin-agarose & 0.38 & 104,000 & 38.000 & 2,534 & 41 \\
\hline
\end{tabular}

* Starting material was 74g fresh ovarian tissue from Bufo females

The sensitivity of casein kinase to heparin in the purified preparation was investigated first. As shown in Fig 1, 90\% of kinase activity toward casein was inhibited in the presence of $1 \mu \mathrm{g} / \mathrm{ml}$ heparin when ATP was used as phosphoryl donor. The $\mathrm{ID}_{50}$ was $0.14 \mu \mathrm{g} / \mathrm{ml}$. Casein kinase activity of the heparin-agarose fraction was also measured with GTP as phosphoryl donor (Fig 1). As expected, the casein kinase activity was totally inhibited in the presence of $1 \mu \mathrm{g} / \mathrm{ml}$ heparin. Thus it may be 
concluded that the major casein kinase activity in the heparin agarose fraction was contributed by CKG itself, while a little (9.0\% of total) emerged from other kinase which was insensitive to the heparin inhibition.

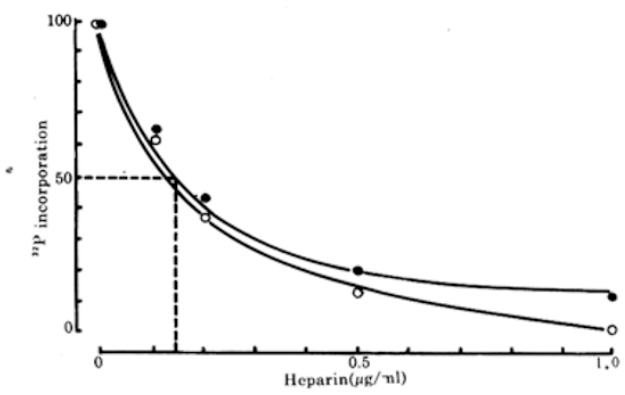

Fig 1. $\triangleleft$ Effect of heparin on casein kinase G activity.

Activity of the purified CKG was measured with $12 \mu \mathrm{M}$ either $\gamma-{ }^{32} \mathrm{P}$-ATP $(\bullet)$ or $\gamma-{ }^{32} \mathrm{P}-\mathrm{GTP}(\circ)$ in the presence of various concentrations of heparin as indicated.

CKG is an $\alpha_{2} \beta_{2}$ tetramer. The enzyme has a molecular weight of 130,000 150,000 and is composed of 2 each copies of catalytic subunits $(\mathrm{Mr}=35,000-44,000)$ and regulatory subunits $(\mathrm{Mr}=24,000-28,000)$. Analysis of the casein kinase from SDS-PAGE gel slices showed that the activity was catalyzed by a protein with a molecular weight of 42,000 (Fig 2), in close agreement with the reported weight of the catalytc subunit of CKG. The casein kinase activity, using ATP as phosphoryl

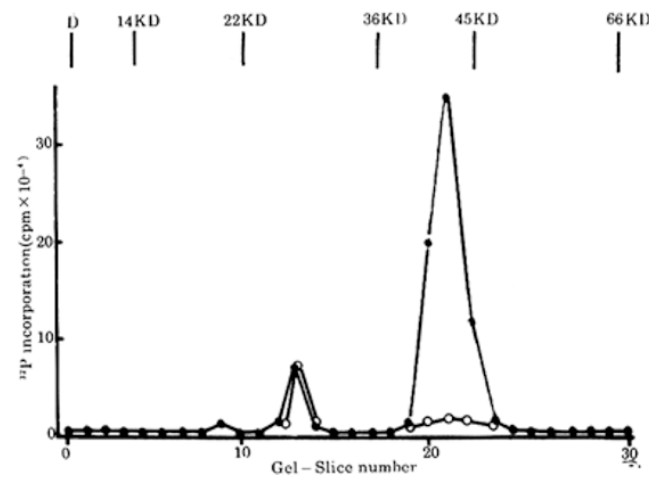

Fig 2. $\triangleleft$ Identification of the catalytic subunit of purified CKG.

After running on SDS-PAGE, the gel slices were treated as described in $\mathrm{Ma}$ terials and Methods, and assayed for their ability to phosphorylate casein in standard conditions without $(\bullet)$ or with (॰) $1.0 \mu \mathrm{g} / \mathrm{ml}$ heparin. Vertical bars, showing the position of molecular weight standards. D, dye front.

donor, catalyzed by $42 \mathrm{kD}$ protein, was strongly inhibited by $1.0 \mu \mathrm{g} / \mathrm{ml}$ of heparin (Fig 2). On the other hand, an unknown kinase towards casein was found in these experiments. Its activity was not sensitive to the heparin inhibition. Although CKG was a heteromeric complex, the catalytic subunit alone was able to catalyze the phosphorylation reaction. The regulatory subunit only stimulated the rate of catalysis and the process of autophosphorylation. Indeed, when the purified CKG was incubated with $\gamma_{-}{ }^{32} \mathrm{p}$-ATP and $\mathrm{Mg}^{2+}$ in the absence of exogenous protein substrate, ${ }^{32} \mathrm{P}$ incorporation was observed to proceed rapidly (Fig 3A). The enzyme incorporated, up to the about $2 \mathrm{~mol}$ of phosphate per mol enzyme (assuming an molecular weight of 150,000 for the enzyme).

A lower dose of casein $(10 \mu \mathrm{g})$ did not exert obvious influence on the rate of ${ }^{32} \mathrm{p}$ 
Casein kinase $\mathrm{G}$ involves in oocyte maturation.

incorporation, indicating an intramolecular phosphorylation mechanism rather than an inter-molecular process in regard to the $\alpha$ subunit of CKG. It was further discovered that a $26 \mathrm{kD}$ protein became labeled in the process of autophosphorylation (Fig 3B), correlated with the $\beta$ subunit of CKG.

The CKG activity did not depend on cAMP, and the inhibitor of cAMP-dependent protein kinase did not influence the kinase activity. However, after the addition of $2 \mathrm{~m} M \mathrm{Ca}^{2+}$ to the incubation medium, the kinase activity was inhibited by $53 \%$. EGTA could stimulated the activity by $37 \%$, probably through chelating minimal dose of $\mathrm{Ca}^{2+}$ in the assay system. Calmodulin could also enhance the activity to a higher level. Whether calmodulin chelated $\mathrm{Ca}^{2+}$ could act as optimal substrate remains unclear. Among tested substrates shown in Tab 2, phosvitin showed highest activity with purified CKG, casein gave about half as much as that of phosvitin, while histone or protamine showed only residual activity.

Under standard assay conditions, spermine was the most potent polyamine which enhanced CKG activity(Fig 4). The kinase activity was increased by $50 \%$ in the presence of either $1.2 \mathrm{~m} M$ spermine or $4.5 \mathrm{~m} M$ spermidine. However, putrescine seemed hardly to be capable of augmenting the activity.

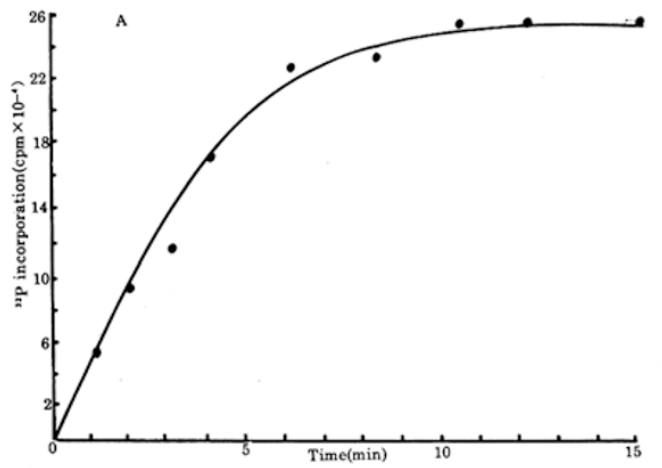

Fig 3A. $\triangle$ Time course of purified CKG autophosphorylation.

Phosphorylation of $7.5 \mu \mathrm{g}$ of the enzyme preparation was carried out by incubating at $33^{\circ} \mathrm{Cin} 50 \mathrm{~m} M$ Tris-HC1 buffer ( $\mathrm{pH}$ 7.2) containing $35 \mu M \quad \gamma_{-}{ }^{32} \mathrm{P}$-ATP, $10 \mathrm{~m} M \mathrm{MgCl}_{2}$, $120 \mathrm{mM} \mathrm{NaCl}$ and $1 \mathrm{~m} M$ EDTA. At the indicated intervals, aliquots were withdrawn and ${ }^{32} \mathrm{P}$-labeled protein was measured as described in Materials and Methods

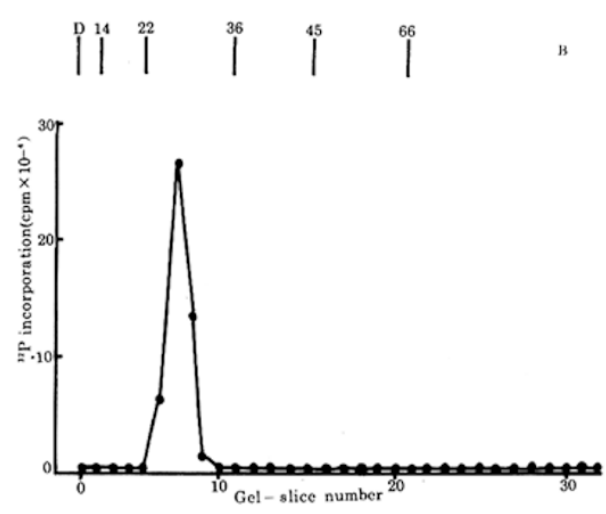

Fig 3B. $\triangle$ Autophosphorylation of CKG. After SDS-PAGE, the gel slices were incubated in the conditions as described in Fig 3A. ${ }^{32} \mathrm{P}$ incorporation into the kinase was measured as described in " Materials and Methods" . D, dye front. Vertical bars, indicating the position of molecular weight markers. 
Tab 2. Characterization of casein kinase G

\begin{tabular}{lc}
\hline $\begin{array}{c}\text { Incubation } \\
\text { with }\end{array}$ & $\begin{array}{c}\text { protein kinase } \\
\text { activity } \%\end{array}$ \\
\hline Casein & 100 \\
+ cAMP $(10 \mu \mathrm{m})$ & 109 \\
+ PKI** $(15 \mathrm{n} M)$ & 111 \\
+ calmodulin $(20 \mu \mathrm{g} / \mathrm{ml})$ & 132 \\
$+\mathrm{Ca}^{2+}(10 \mathrm{~m} M)$ & 44 \\
$+\mathrm{EDTA}^{2+}(2 \mathrm{~m} M)$ & 144 \\
+ $\mathrm{Mg}^{2+}(2 \mathrm{~m} M)$ & 36 \\
Phosvitin & 210 \\
Histone & 8 \\
Protamin & 3 \\
\hline
\end{tabular}

* The substrate concentrations were $\mathrm{l} \mathrm{mg} / \mathrm{ml}$ and the protein kinase activity was expressed relative to casein (as $100 \%$ ).

** Protein kinase inhibitor.

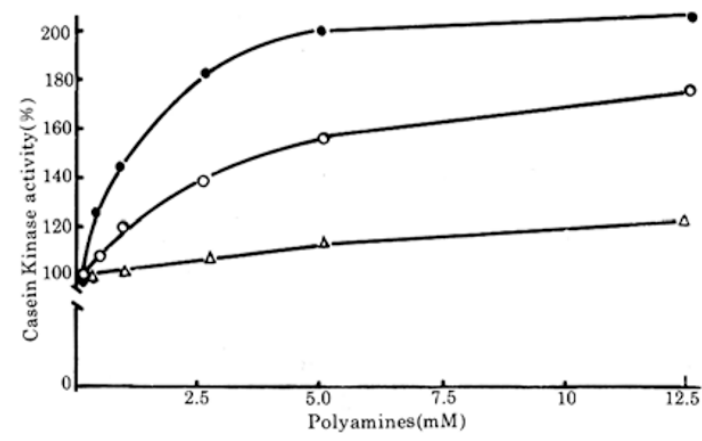

Fig 4. $\triangle$ Effect of different polyamines on CKG activity.

$(\bullet)$, spermine. $(\circ)$, spermidine. $(\triangle)$ Putrescine. Protein kinase activity was compared with that in the absence of polyamine.

\section{Effect of casein kinase $G$ on oocyte maturation}

We have obtained a total potency of 92,000 U CKG activity (heparin-sensitive casein kinase activity) from $74 \mathrm{~g}$ of fresh ovarian tissue of 2 Bufo females which contained approximately 24,000 full-grown oocytes, each containing $1.9 \mathrm{U}$ of CKG activity. Therefore, it would be of great interest to analyze the effect of the kinase on oocyte maturation.

The results of the pretreatment of ooeytes with purified CKG $2 \mathrm{~h}$ prior to progesterone stimulation were shown in Fig 5 . Ooeytes were not capable of undergoing GVBD when each of them was injected with $4.5 \mathrm{U}$ of the enzyme. The $\mathrm{ID}_{50}$ for the kinase inhibition was $0.38 \mathrm{U}$. The kinase buffer both without $\mathrm{Mg}^{2+}$ and with BSA $(1.0 \mathrm{mg} / \mathrm{ml})$ did not affect the kinetics of progesterone-induced maturation, and so was the case in heated kinase preparation $\left(100^{\circ} \mathrm{C}, 5 \mathrm{~min}\right)$. However, GVBD with the frequency of $37-84 \%$ could be induced if $1.5 \mathrm{U}$ of the enzyme together with 100 $\mu \mathrm{g} / \mathrm{ml}$ heparin were injected into the progesterone stimulated Bufo oocytes. The antagonistic effect of heparin toward the kinase activity remained remarkably high even when it was injected $2 \mathrm{~h}$ after hormone stimulation. It may be concluded that the inhibition of GVBD was resulted from the CKG and not due to other protein contaminations in the enzyme preparation. We have further explored whether spermine can exert inhibitory effect on GVBD mediated by CKG. Earlier we have found that $2.5 \mathrm{in} M$ spermine delayed the kinetics of progesterone-induced oocyte maturation [8]. As was expected, $2.5 \mathrm{~m} M$ spermine significantly enhanced the enzyme inhibitory effect on GVBD when oocytes were injected with spermine $1 \mathrm{~h}$ after the injection of the enzyme (Fig 5). The $\mathrm{ID}_{50}$ for the kinase inhibition was $0.22 \mathrm{U}, 42 \%$ lower than that when the kinase was injected alone. We have observed that all the 
Casein kinase $\mathrm{G}$ involves in oocyte maturation.

Fig 5. $\triangleright$ Effect of CKG on progesterone induced Bufo oocyte maturation. After microinjection of casein kinase, groups of 80-100 oocytes were incubated in Ringer's solution as control (-), or Ringer's solution containing $0.05 \mathrm{~m} M$ IBMX $(\square)$, or $0.20 \mathrm{mM}$ 5'-deoxy-5'isobutyladenosine $(\triangle)$, or microinjected with $100 \mathrm{nl}$ of $2.5 \mathrm{mM}$ spermine $(\bigcirc)$, and induced to mature, $2 \mathrm{~h}$ later, in Ringer's solution containing $1 \mu M$ progesterone. GVBD were observed $12 \mathrm{~h}$ after hormone stimulation.
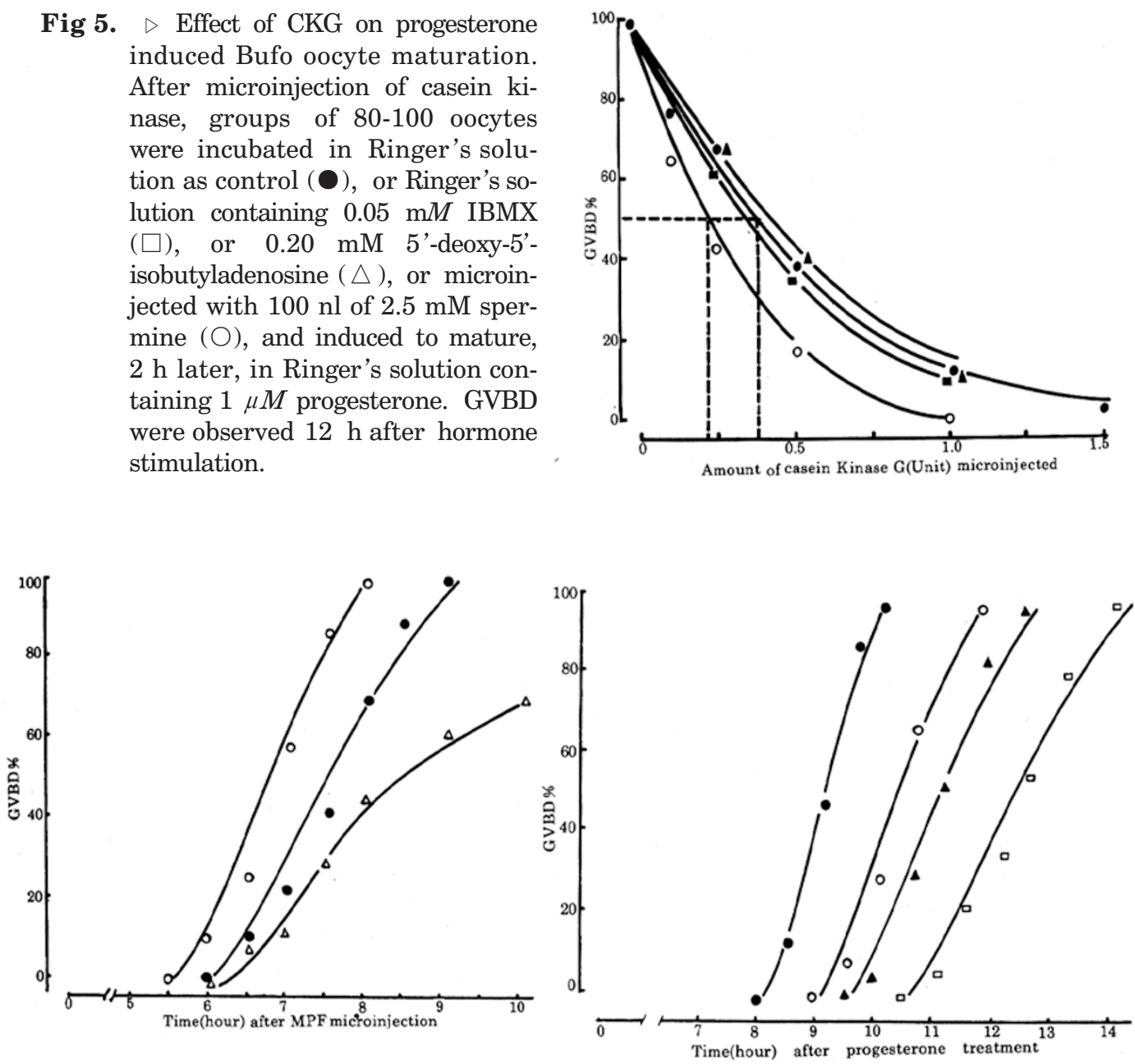

Fig 6. $\triangle$ Effect of CKG on MPF- induced Bufo oocyte maturation.

Groups of 15-20 oocytes were microinjected either with $\mathrm{Mg}^{2+}$-free kinase buffer as control (०), with $1.5 \mathrm{U}$ of highly-purified CKG $(\bullet)$, or with $4.0 \mathrm{U}$ of the kinase $(\triangle) 2 \mathrm{~h}$ prior to the microinjection of $100 \mathrm{nl}$ cytoplasm containing MPF from maturated oocytes. GVBD were scored $8 \mathrm{~h}$ after the MPF injection.

Fig 7. $\triangle$ Release of the spermine inhibition effect on oocyte maturation by heparin. Groups of 15-20 oocytes were microinjected with $5 \mathrm{~m} M$ Tris- $\mathrm{HC} 1$ buffer $(\mathrm{pH}$ 7.4) as control (०), or the buffer containing $2.5 \mathrm{mM}$ spermine $(\square)$, or 10 $\mu \mathrm{g} / \mathrm{ml}$ of heparin $(\bullet)$, or microinjected with $100 \mathrm{nl}$ of $2.5 \mathrm{mM}$ spermine $1 \mathrm{~h}$ after the treatment of heparin $(\triangle)$, and then induced to mature, $1 \mathrm{~h}$ later, in Ringer solution containing $1 \mu \mathrm{M}$ progesterone.

ooytes were capable of undergoing GVBD with a delayed time course of matura- 
tion when incubated in Ringer solution containing $0.05 \mathrm{~m} M$ IBMX (3-isobutyl-1methylxanthine), an inhibitor of cAMP phosphodiesterase, and $0.20 \mathrm{~m} M 5$-deoxy5 '-isobutyl-adenosine, an inhibitor of phospholipid methyltransferese (unpublished data), respectively. But neither of them was found to be capable of promoting the effect of the kinase on oocyte maturation (Fig 5), indicating that the enhancement of the kinase inhibition exerted by spermine was specific, and this might be due to an increase of endogenous kinase activity in the presence of spermine.

As shown in Fig 6, MPF-induced maturation was considerably delayed in the kinase-treated Bufo oocytes. Oocytes were capable of undergoing GVBD with a frequency of about $42 \%, 8 \mathrm{~h}$ after receiving cytoplasm containing MPF. $\mathrm{Mg}^{2+}$ in kinase buffer must be removed by dialysis since it would interfere with the kinetics of MPF -induced Bufo oocyte maturation. It was obvious that CKG may regulate the oocyte maturation negatively. As a line of supporting evidence, we have found that heparin $(10 \mu \mathrm{g} / \mathrm{ml})$, a specific inhibitor of CKG, accelerated the rate of steroid-induced oocyte maturation, and the positive effect of heparin was antagonized by spermine when they were injected simultaneously into the oocytes (Fig 7).

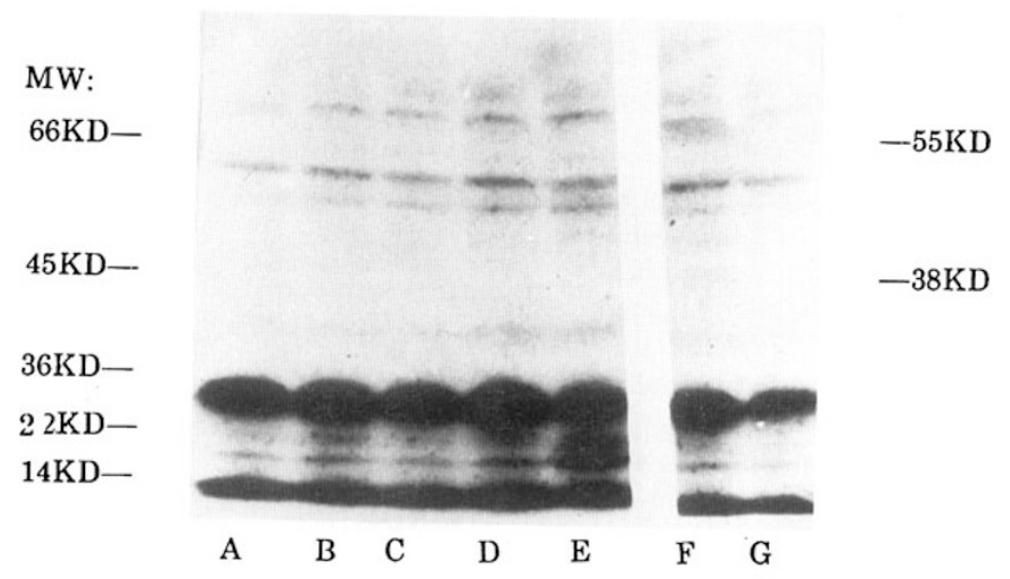

Fig 8. $\triangle 7.5-15 \%$ SDS-PAGE autoradiographic profiles of proteins phosphorylated from CKG treated oocyte cytosolic extract.

Bufo oocytes were homogenized in $50 \mathrm{~m} M$ Tris-HCl buffer (pH 7.2) containing $1 \mathrm{mM}$ PMSF, $10 \mathrm{mM} \mathrm{MgCl} 2,1 \mathrm{mM}$ EDTA and $1 \mathrm{mM}$ EGTA.

The $2000 \times \mathrm{g}$ supernatant $(400 \mu \mathrm{g}$ proteins, $30 \mu \mathrm{l})$ was added with different doses of highly purified CKG: $0 \mathrm{U}$ in lane A; $50 \mathrm{U}$ in lane $\mathrm{B} ; 100 \mathrm{U}$ in lane C; $150 \mathrm{U}$ in lanes $\mathrm{D}$ and $\mathrm{E}$. Additionally, $0.5 \mathrm{mM}$ of spermine was added into the $2000 \times$ g supernatant in lanes $\mathrm{E}$ and $\mathrm{F}$; heparin $(10 \mu \mathrm{g} / \mathrm{ml})$ was added into the supernatant in lane G. Finally, $10 \mu \mathrm{M}$ of $\gamma{ }^{32} \mathrm{P}$-ATP was added into the supernatant in all the lanes. The mixtures were incubated for $2 \mathrm{~h}$ at $31^{\circ} \mathrm{C}$ and then added equal volume of Sample buffer (Laemmli, 1970) for SDS-PAGE: The dried gel was submitted to autoradiography. 
Casein kinase $\mathrm{G}$ involves in oocyte maturation.

\section{Identification of the endogenous substrate of the CKG}

A relatively direct evidence in vitro that a $55 \mathrm{kD}$ protein may be the substrate of CKG was shown in Fig 8. The-addition of purified CKG into an incubation medium of the crude extract of Bufo oocytes selectively phosphorylated the $55 \mathrm{kD}$ protein in an activity-dependent manner(Fig 8). The $55 \mathrm{kD}$ protein phosphorylation, catalyzed by the kinase from the extract, was enhanced by spermine and inhibited by heparin, proving that endogenous CKG indeed regulated the $55 \mathrm{kD}$ protein phosphorylation. We further investigated the effect of CKG on protein phosphorylation in vivo. The phosphorylation of $55 \mathrm{KD}$ proteins was enhanced in the kinase-treated oocytes (Fig 9). However, the enzyme promoted the dephosphorylation of $38 \mathrm{kD}$ proteins. In the meantime, the change of phosphorylation pattern $38 \mathrm{kD}$ proteins were not observed in the mature oocytes as compared with those of immature oocytes, showing that the basal phosphorylation changes of these 2 proteins were independent of progesterone-induced oocyte maturation. On the other hand, the $55 \mathrm{kD}$ protein was dephosphorylated in the: mature oocytes, and the change was inhibited by microinjection of the kinase, consistent with the GVBD inhibition. It seemed evident that the enhanced endogenous kinase-induced $55 \mathrm{kD}$ protein phosphorylation, as a result of the kinase treatment, was responsible for the failure of GVBD.

Fig 9. $\triangleright 7.5-15 \%$ SDS-PAGE autoradiographic profiles of proteins phosphorylated by CKG microinjected oocytes.

Oocytes were microinjected with $\gamma$ - ${ }^{32} \mathrm{P}$-ATP $(1.5 \mu \mathrm{Ci} /$ oocyte $) .1$ $\mathrm{h}$ later, oocytes in lanes $\mathrm{A}$ and $\mathrm{C}$ were injected with modified kinase buffer which was omitted with $\mathrm{Mg}^{2+}$ and added with BSA (1 $\mathrm{mg} / \mathrm{ml}$ ); oocytes in lanes B and D were injected with the buffer containing highly purified CKG (1.5 U /oocyte); oocytes in $\mathrm{C}$ and $\mathrm{D}$ were induced to mature, $1 \mathrm{~h}$ later, in Ringer's solution containing $1 \mu M$ progesterone.

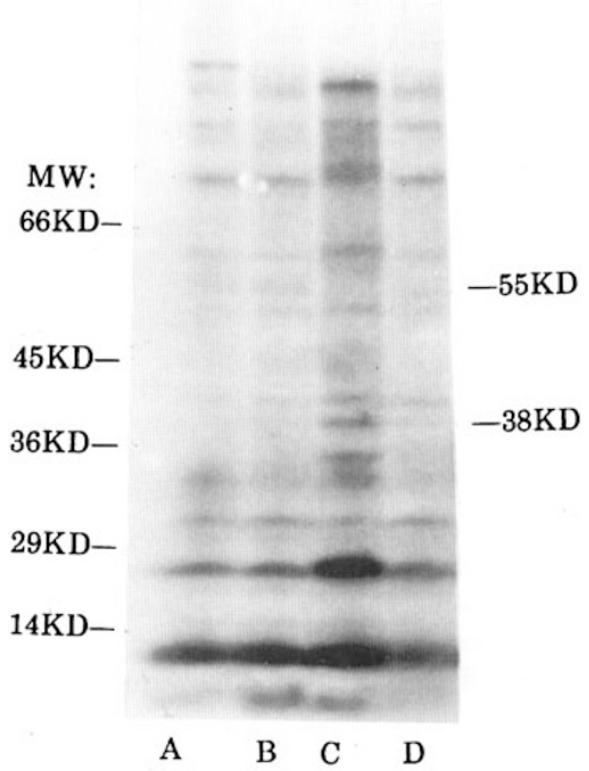

\section{DISCUSSION}

In a previous paper[8], we have reported that polyamines, spermine and spermi- 
dine, were capable of inhibiting progesterone-induced Bufo oocyte maturation. In order to explore further the mechanism of oocyte maturation inhibition by spermine, we purified CKG from toad ovaries with an enrichment of more than 2,500-fold with respect to the crude extract through 3 successive column chromatographic separations.

The CKG from Bufo ovaries was preferable to phosphorylate acidic proteins such as phosvitin and casein, using both ATP and GTP as the phosphoryl donor. The kinase activity toward casein was totally inhibited by a low dose of heparin with $\mathrm{ID}_{50}$ at $0.14 \mu \mathrm{g} / \mathrm{ml}$ (Fig 1 ). The activity was also repressed by $\mathrm{Ca}^{2+}$ and disappeared in the absence of $\mathrm{Mg}^{2+}$ (unpublished data), but was activated in the presence of millimolar concentrationa of polyamines (Fig 4) and was not affected by cAMP or proten kinase inhibitior (Tab 2), in close agreement with the data on these effectors described for CKG[17]. Our highly purified casein kinase autophosphorylated in the absence of exogenous protein substrate (Fig 3A), in which a $26 \mathrm{kD}$ protein was catalyzed (Fig 3B) and was detected to be devoid of any intrinsic casein kinase activity. The kinase activity was catalyzed by a $42 \mathrm{kD}$ protein (Fig 2). The $42 \mathrm{kD}$ protein and the $26 \mathrm{kD}$ protein were well correlated with $\alpha$ (catalytic) and $\beta$ (regulatory) subunit of CKG, respectively[9,10]. Our purified enzyme, therefore, was indeed CKG according to the above-stated criteria. About 38,000 $\mathrm{U}$ of enzyme with a yield of $41 \%$ have been obtained from $74 \mathrm{~g}$ of fresh ovaries, which contained approximately 24,000 full-grown oocytes (diameter=1.7-1. 8 ram). It may be calculated that each full-grown Bufo oocyte embodies about $93 \mathrm{nM}$ (1.9 U) of CKG (assuming that the enzyme molecular weight was 130,000 Da. and the diffusion volume in Bufo oocytes to be $1.5 \mu \mathrm{l}$ ), if half of the enzyme found in the ovaries came from full-grown Bufo oocytes, as proposed by Mulner-Lorillon et a1[18] in Xenopus oocytes.

We have paid much attention to the effect of CKG on oocyte maturation. As was expected, the purified enzyme was observed to inhibit oocyte maturation induced by progesterone, $\mathrm{ID}_{50}$ was $0.38 \mathrm{U}$ (Fig 5). $1.5 \mathrm{U}$ of microinjected enzyme was enough to inhibit completely the oocyte maturation, corresponding to $67 \mathrm{n} M$ internal concentration of the enzyme.

Up to now, some kind of protein kinase have been proved to implicate in the negative control of cell cycle, such as cAMP-dependent protein kinase activity in meiosis maturation of Xenopus oocytes[2], protein kinase $\mathrm{C}$ in the cells which began to synthesize DNA[19], a putative protein kinase encoded by Wee 1 gene in the $\mathrm{G}_{2} / \mathrm{M}$ transition of S. pombe[20] and a putative P34cdc $\mathrm{c}_{2}$ kinase involved in the initiation of mitosis and meiosis[20,21]. All these negative and positive effects which were exerted by different protein kinases maybe a general reflection of the mechanism for the control of cell cycle.

While our work was proceeding, Mulner-Lorrillon et al have published their paper indicating that highly purified CKG could inhibit progesterone-induced Xenopus oocyte maturation[18]. They speculated that the kinase might be phosporylate "Maturation protein" (Mp) or the regulatory protein involved in Mp phosphoryla- 
Casein kinase $\mathrm{G}$ involves in oocyte maturation.

tion/dephosphorylation We have observed that microinjection of physiological doses of the kinase could delay or inhibit the MPF-induced maturation of toad oocytes (Fig 6).

What is the molecular mechanism by which CKG inhibits Bufo oocyte maturation? As we analyzed the profile of ${ }^{32} \mathrm{P}$-labelled proteins in the kinase-treated oocytes, it was revealed that the extent of the phosphorylation of $55 \mathrm{kD}$ protein was parallel to the increased amount of kinase used (Fig 8). The dephosphorylation of the protein has been implicated in the process of oocyte maturation induced by progesterone[8]. Therefore, the $55 \mathrm{kD}$ protein phosphorylation promoted by CKG may result in failure of oocyte maturation in the kinase-treated oocyte since the dephosphorylation of the protein has never been observed in these oocytes.

Gochet and Chambaz[9] have proposed that the endogenous polyamines may act as an universal regulator of $\mathrm{CKG}$, since the enzyme activity was enhanced in the presence of physiological doses of polyamines in vitro, and the cellular levels of polyamines were accurately controlled. However, this suggestion has not been proved perhaps due to the lack of evidence of endogenous substrates for the kinase. Fortunately, strong support for the suggestion have come from the data which we have sofar obtained:

1). Under our assaying conditions, a 2-fold activation of CKG activity was observed in the presence of $2.5 \mathrm{~m} M$ spermine (Fig 4). The efficiency of spermine induced activation was dependent on the conditions of assaying. Although the reduction by only $28 \%$ of endogenous spermine level was measured at the end of oocyte maturation induced by progesterone, a large stock of spermine may appear in the vegetal pole of Bufo oocyte[8] which did not participate in the regulation of oocytes maturation. Intracellular compartment of spermine could also be found in mammalian cells[22]. The compartment of spermine may obscure the magnitude of fluctuation in regulatory pools of spermine. A similar case in regard to cAMP was observed in the process of oocyte maturation[23]. Therefore, the decreased in endogenous spermine level can render the kinase activity to decrease significantly in vivo. The presence of kinase-specific inhibitor may amplify the range of the polyamine-modulated CKG activity[9].

2). Spermine and CKG all inhibited progesterone-induced oocyte maturation [8 and this paper]. The combined effect of spermine and CKG on oocyte maturation (Fig 5) was stronger than the sum of their separate inhibitory effectes, suggesting the existence of CKG activation in vivo by spermine.

3). The spermine inhibitory effect was closely associated with enhancement of the $55 \mathrm{kD}$ protein phosphorylation in a time and dose dependent manner[8]. The GKG inhibitory effect was also coupled with the enhanced $55 \mathrm{kD}$ protein phosphorylation(Fig 9). The $55 \mathrm{kD}$ protein was proved to be the endogenous substrate of CKG since the addition of the purified kinase and spermine enhanced selectively the phosphorylation of the $55 \mathrm{kD}$ protein in the crude extract which could be inhibited by a low dose of heparin (Fig 8). Therefore, oocyte CKG may be the physiological 
target of spermine, and its activity was controlled by endogenous spermine,

The phosphatase activity toward the $55 \mathrm{kD}$ protein may not respond to spermine inhibition, since the inhibitors of some well-known phosphatases, unlike spermine, were unable to inhibit the oocyte maturation, We did not know whether these phosphatases were also responsible to the dephosphorylation of the $55 \mathrm{kD}$ protein. But the rate-limiting enzyme of $55 \mathrm{kD}$ protein dephosphorylation may be CKG rather than the phosphatases, as the reduced level of spermine was detected during the period when $55 \mathrm{kD}$ protein dephosphorylation actually happened[8].

Many proteins like eukaroytic initiation factor eIF2 [24], fibrinogen[25], $\beta$-light chain of clathrin[26] and $90 \mathrm{kD}$ heat shock protein[27], myc oncoprotein[28], microtubule-associated protein-1 [29], $\beta$-tubulin[30] and so on have been shown to be phosphorylated by CKG in vitro. But no protein, as far as we know, has yet been identified to be phosphorylated by the kinase in vivo. The $55 \mathrm{kD}$ protein was phosphorylated by the kinase both in vitro and in vivo (Figs 8 and 9). Cells of huge size "Giant cells", such as oocytes of amphibian, allowed us to perform microsurgical operation and thus came close to in vivo conditions.

\section{REFERENCES}

[1] Krebs EG, Beano B. Phosphorylation and dephosphorylation of enzymes. Ann Rev Biochem 1979; 48:923-59.

[2] Maller JL, Krebs EG. Progesterone-induced meiotic cell division in Xenopus oocytes: Induction by the regulatory subunit and inhibition by the catalytic subunit of cAMP-dependent protein kinase. J Biol Chem 1977; 252:1712-8.

[3] Kostellow AB, Chien EJ, Morril GA. Calcium-dependent phosphorylation of amphibian oocyte plasma membrane: an early event in initiating the meiotic maturation. Biochem Biophys Res Commun 1987; 147:863-9.

[4] Labbe JC, Picard A, Karsenti E, Doree M. An M-phase-specific protein kinase of Xenopus oocytes: partial purification and possible mechanism of its activation. Dev Biol 1988; 127:15769.

[5] Lokha MJ, Hayes MK, Maller JL. Purification of maturation-promoting factor, an intracellular regulator of early mitosis events. Proc Natl Acad Sci (USA) 1988; 85:3009-13.

[6] Wu M, Gerhart J. Partial purification and characterization of the maturation-promoting factor from eggs of Xenopus laevis. Dev Biol 1980; 79:465-77.

[7] Stith B J, Mallet JL. Increased intracellular pH is not necessary for ribosomal protein S6 phosphorylation, increased protein synthesis, or germinal vesicle breakdown in Xenopus oocytes. Dev Biol 1985; 107:460-9.

[8] Li PS, Tso J. Study on the physiological function of spermine in the process of progesterone induced toad oocyte maturation. Cell Res 1992; 2:103-17.

[9] Cochet C, Chambaz EM. Polyamine-mediated protein phosphorylation: a possible target for intracellular polyamines action. Mol Cell Endocr 1983; 30:247-66.

[10] Sommercon J, Mulligan JA, Lozenmen F J, Krebs EG. Activation of casein kinase II in response to insulin and epidermal growth factor. J Biol Chem 1987; 282:3839-43.

[11] Schreider HR, Reichert GH, Issinger OG. Enhanced casein kinase II activity during mouse embryogenesis. Eur J Biochem 1986; 161: 733-8.

[12] Hathaway GM, Lubben TH, Traugh JA. Inhibition of casein kinase II by heparin. J Biol Chem 1980; 255:8038-41. 
Casein kinase $\mathrm{G}$ involves in oocyte maturation.

[13] Boyer J Belle R, Huchon D, Ozon R.In ovo protein kinase activity during progesterone-induced maturation of Xenopus oocytes. In: Delrio G, Brachet J. ed. Steroid and their mechanisms of action in non-mammalian vertevrates. Raven Press (New York) 1980; 85-92

[14] Ozon R, Mulner O, Boyer J, Belle R. Role of protein phosphorylation in Xenopus oocyte meiotic maturation. In: Schlegel RA, Halleck MS, Rao PN. ed. Molecular regulation of nuclear events in meiosis and mitosis. Academic Press (London) 1987; 111-30.

[15] Laemmli UK. Cleavage of structure proteins during the assembly of the head of bacteriophage T4. Nature (London) 1970; 277:680-5.

[16] Bradford M. A rapid and sensitive method for quantitation for microgram of protein using the principle of protein-dye binding. Anal Biochem 1976: 72:248-54.

[17] Hathaway GM , Traugh JA. Mechanism of casein kinase II, cAMP-independent protein kinase, by 2,3-diphosphoglycerate and pyridoxal 5'- phosphate. Fed Proc 1982; 41:872.

[18] Mulner-LorillomO, Marot J, Cayla X, Pouhle R, Belle R. Purification and characterization of a casein kinase II type enzyme from Xenopus laevis ovary. Eur J Biochem 1988; 171:107-17

[19] Takai Y. Functions of protein kinase $\mathrm{C}$ in positive and negative cellular regulation. Fed Proc 1987; 46:1925.

[20] Russel P, Nurse P. Negative regulation of mitosis by Wee 1', a gene encoding a protein kinase homology. Cell 1987: 49:559-67.

[21] Meijer L, Arion D, Golsteyn R, Pines J, Brizuela L, Hunt T, et al. Cyclin is a component of the sea urchin egg M-phase-specific histone kinase. EMBO J 1989; 8:2275-82.

[22] Mach M, Ebert P, Popp R, Olivie A. Compartmentalization of polyamines in mammalian cells. Biochem Biophys Res Commum 1982; 104:1327-34.

[23] Maller JL, Krebs EG. Regulatiom of oocyte maturation. Curr Top Cell Regulation 1980; 16:271311.

[24] Rittschof D, Traugh A. Purification of messenger ribonucleoproptein particles from rabbit reticulocytes by zonal centrifugation in metrizamide. Eur J Biochem 1981; 115:45-52.

[25] Guasch MD, Plana M, Pena JM, Itarte E. Phosphorylaeion of fibrinogen by casein kinase II. Biochem J 1986; 234:523-6

[26] Bar-Zvi D, Branton D. Clathrin-coated vesicles contain two protein kinase activities. J Biol Chem 1986; 261:9614-21.

[27] Dougherty JJ, Rabideau DA. Iannetti AM, Sullivan WP,Tolf DO. Identification of the $90 \mathrm{kD}$ substrate of rat liver type II casein kinase II with heat shock protein which binds steroid receptor. Biochem Biophys Acta 1987; 927:74-80.

[28] Luschner B, Kuenzel EA, Krebs EG, Eisenman RN. Myc oncoprotein is phosphorylated by casein kinase II. EMBO J 1989; 8:1111-9.

[29] Diaz-Nido J, Serrano L, Mendee E, Avila J. A casein kinase II-related activity is involved in phosphorylation of differentiation. J Cell Biol 1988;106:2057-65.

[30] Serrano L, Diaz-Nido J, Wandosell F, Avile J. Tubulin phosphorylation by casein kinase II is similar to that found in vivo. J Cell Biol 1987; 105:1731-9.

Received 31-10-91. Revised 5-8-92. Accepted 25-8-92. 